- Increases awareness of how GDPs perceive the benefits of teledentistry for orthodontic referrals.

- Before teledentistry becomes more widespread, we have information regarding GDP opinion on such a referral system.

- It will be important to address GDP concerns about setting up expenses and appropriate remuneration for teledentistry referrals.

\title{
Teledentistry for screening new patient orthodontic referrals. Part 2: GDP perception of the referral system
}

\author{
N. A. Mandall, ${ }^{1}$ U. Quereshi ${ }^{2}$ and L. Harvey ${ }^{3}$
}

\begin{abstract}
Objective To evaluate GDP opinion about a teledentistry system to screen new patient orthodontic referrals.

Study design Cross-sectional questionnaire.

Sample Two hundred general dental practitioners (GDPs) were approached from Stockport, Rochdale, Oldham, Bury and Bolton in Greater Manchester, and High Peak in Derbyshire.

Method A questionnaire about a teledentistry system for new orthodontic patients was developed, following interviews with eight GDPs participating in a teledentistry trial. The questionnaire was posted to another 200 GDPs who were asked questions on issues such as the efficiency of a teledentistry system; the usefulness of a teledentistry system from the patients' point of view; their view of a teledentistry system; and any concerns they had relating to security, confidentiality and consent.

Results Seventy one per cent of GDPs thought teledentistry for orthodontic referrals would be a good idea. At least $90 \%$ of responders agreed or neither agreed nor disagreed that patients would benefit from such a system. Over half of GDPs agreed or strongly agreed that there would be implications on their surgery time, expense and equipment security.

Conclusions GDPs generally supported a teledentistry system for new patient orthodontic referrals. Although perceived patient advantages were agreed, GDPs tended to be less sure about the impact on them in terms of set-up expenses, time in the surgery and appropriate remuneration.
\end{abstract}

\section{INTRODUCTION}

The aim of this study was to evaluate GDP opinion about a 'store and forward' teledentistry system to screen new patient orthodontic referrals. This is important because issues such as remuneration for time spent taking and emailing photographs, the availability of a practice computer and concerns about patient confidentiality may become apparent when teledentistry becomes more widespread. These opinions, sought now, may

\footnotetext{
${ }^{1^{*}-4}$ Orthodontic Department, University Dental Hospital of Manchester, Higher Cambridge Street, M15 6FH

*Correspondence to: Dr N. A. Mandall

Email:nicky@fs1.den.man.ac.uk
}

\section{Refereed paper}

Accepted: 21 October 2004

doi: 10.1038/sj.bdj.4812969

๑ British Dental Journal 2005; 199: 727-729 facilitate the introduction of teledentistry in the future without engendering GDP opposition.

Telemedicine or teledentistry combines computers, telecommunications and medical expertise to enable health professionals to provide diagnostic and consulting services from locations distant from their patients. ${ }^{1}$ At present, the specialties leading the use of telemedicine are radiology, pathology, dermatology, psychiatry and cardiology. ${ }^{2}$ Telemedicine has also been used for oral and maxillofacial assessment. ${ }^{3}$

Teledentistry would appear to have advantages as a method for providing orthodontic advice, as a recent study has shown that clinical opinions given by this route using images of case records do not differ from those given when the records are handled directly. ${ }^{4}$ While technically, teledentistry systems are feasible, we considered it important to evaluate the opinions of GDPs as potential users.

\section{METHOD}

\section{Sample}

Two hundred general dental practitioners (GDPs) were approached from Stockport, Rochdale, Oldham, Bury and Bolton in Greater Manchester, and High Peak in Derbyshire. All GDPs in these areas were asked to participate in the study. In addition none of these GDPs were aware of the results of the teledentistry trial reported in Part 1.

The study was done in two stages:

- The development of a questionnaire

- GDP opinion based on the developed questionnaire.

\section{Development of the questionnaire}

Author UQ interviewed eight GDPs who were taking part in a teledentistry trial to screen new orthodontic patients. These interviews were recorded and transcribed verbatim. Each GDP was asked to comment on a store and forward email system being used to assess orthodontic referrals. The process involved the referring GDP sending digital extra oral and intra oral patient photographs and radiographs, if available, to a consultant orthodontist. The orthodontist then decided whether the patient should be sent in to a new patient clinic, using factors such as severity of malocclusion, stage of dental development and oral hygiene.

From the transcribed interviews, common ideas and opinions emerged from which questions were formulated. The key areas were: - Efficiency of a teledentistry system 


\begin{tabular}{|c|c|c|c|c|c|}
\hline & \multicolumn{5}{|c|}{ Frequency (Valid \%) } \\
\hline & Agree & $\begin{array}{l}\text { Agree } \\
\text { strongly }\end{array}$ & $\begin{array}{l}\text { Neither } \\
\text { agree } \\
\text { nor } \\
\text { disagree }\end{array}$ & $\begin{array}{l}\text { Disagree } \\
\text { strongly }\end{array}$ & Disagree \\
\hline $\begin{array}{l}\text { Teledentistry for } \\
\text { orthodontic referrals } \\
\text { is a good idea }\end{array}$ & $28(22 \%)$ & $62(49 \%)$ & $25(20 \%)$ & $8(6 \%)$ & $4(3 \%)$ \\
\hline \multicolumn{6}{|l|}{$\begin{array}{l}\text { A teledentistry } \\
\text { system would: }\end{array}$} \\
\hline $\begin{array}{l}\text { Be better than a } \\
\text { referral letter }\end{array}$ & 22 (17\%) & $52(40 \%)$ & 38 (29\%) & $14(11 \%)$ & $4(3 \%)$ \\
\hline $\begin{array}{l}\text { Make referral of } \\
\text { new patients more } \\
\text { efficient }\end{array}$ & 23 (18\%) & 60 (47\%) & $28(22 \%)$ & $13(10 \%)$ & $4(3 \%)$ \\
\hline $\begin{array}{l}\text { Improve } \\
\text { communications } \\
\text { between } \\
\text { clinicians }\end{array}$ & $32(25 \%)$ & 71 (55\%) & $20(15 \%)$ & $7(5 \%)$ & 0 \\
\hline $\begin{array}{l}\text { Enhance guidance } \\
\text { and advice }\end{array}$ & 34 (26\%) & 70 (53\%) & $16(12 \%)$ & $10(8 \%)$ & $1(1 \%)$ \\
\hline $\begin{array}{l}\text { Help shorten } \\
\text { waiting lists }\end{array}$ & $26(20 \%)$ & 44 (34\%) & 41 (32\%) & 14 (11\%) & $5(4 \%)$ \\
\hline $\begin{array}{l}\text { A live video link } \\
\text { would be better } \\
\text { than an email } \\
\text { photo attachment }\end{array}$ & $18(14 \%)$ & $29(23 \%)$ & $39(30 \%)$ & $35(27 \%)$ & $8(6 \%)$ \\
\hline
\end{tabular}

\begin{tabular}{|c|c|c|c|c|c|}
\hline & \multicolumn{5}{|c|}{ Frequency (Valid \%) } \\
\hline & $\begin{array}{l}\text { Agree } \\
\text { strongly }\end{array}$ & Agree & $\begin{array}{l}\text { Neither } \\
\text { agree } \\
\text { nor } \\
\text { disagree }\end{array}$ & $\begin{array}{l}\text { Disagree } \\
\text { strongly }\end{array}$ & Disagree \\
\hline \multicolumn{6}{|l|}{$\begin{array}{l}\text { A teledentistry } \\
\text { system would: }\end{array}$} \\
\hline $\begin{array}{l}\text { Be well received } \\
\text { by patients }\end{array}$ & $18(14 \%)$ & $75(58 \%)$ & $33(25 \%)$ & $3(2 \%)$ & $1(1 \%)$ \\
\hline $\begin{array}{l}\text { Be convenient } \\
\text { for patients }\end{array}$ & $19(15 \%)$ & $81(62 \%)$ & $20(15 \%)$ & $6(5 \%)$ & $4(3 \%)$ \\
\hline $\begin{array}{l}\text { Help reduce } \\
\text { unnecessary travel } \\
\text { to hospital }\end{array}$ & 38 (29\%) & 74 (57\%) & $10(8 \%)$ & $5(4 \%)$ & $4(3 \%)$ \\
\hline $\begin{array}{l}\text { Be useful for } \\
\text { patients in distant } \\
\text { or rural locations }\end{array}$ & $55(42 \%)$ & $64(49 \%)$ & $9(7 \%)$ & $1(1 \%)$ & $1(1 \%)$ \\
\hline $\begin{array}{l}\text { Help with patient } \\
\text { information and } \\
\text { education }\end{array}$ & $20(15 \%)$ & $68(52 \%)$ & $35(27 \%)$ & $6(5 \%)$ & $2(2 \%)$ \\
\hline $\begin{array}{l}\text { Improve interaction } \\
\text { and communication } \\
\text { with patients }\end{array}$ & $22(17 \%)$ & 61 (47\%) & 41 (31\%) & $4(3 \%)$ & $3(2 \%)$ \\
\hline $\begin{array}{l}\text { Stop unnecessary } \\
\text { hospital appointments } \\
\text { for patients }\end{array}$ & $37(28 \%)$ & 75 (57\%) & $12(9 \%)$ & $4(3 \%)$ & $3(2 \%)$ \\
\hline
\end{tabular}

- The usefulness of a teledentistry system from the patients' point of view

- The GDPs' view of a teledentistry system

- GDPs' concerns relating to security, patient confidentiality and consent.
This resulted in a 24-item questionnaire. The response to each question was recorded on a five-point Likert scale where:

$1=$ agree strongly

2 = agree

$3=$ neither agree nor disagree

$4=$ disagree

5 = disagree strongly.

\section{GDP opinion of a teledentistry system}

The questionnaire was sent to 200 GDPs with an explanation of the store and forward email system for new patient orthodontic referrals. The explanation covered the use of a brief referral proforma and the use of clinical photographs and radiographs as email attachments. Photographs were downloaded from a digital camera and radiographs placed in a light box and photographed which gave a high quality radiographic image. A second questionnaire was sent to all GDPs who did not respond to the first mailing.

\section{Statistics}

Simple summary statistics were calculated for each question.

\section{RESULTS}

A $65.5 \%$ response $(n=131)$ was obtained. Overall, $71 \%$ of GDPs thought teledentistry for orthodontic referrals would be a good idea (Table 1).

\section{Efficiency of a teledentistry system}

Generally, GDPs were positive about the potential benefits of a teledentistry system. In addition, 75\% agreed or strongly agreed that communication between clinicians would improve and guidance and advice would be enhanced. Respondents were less convinced that electronic referrals would be better than referral letters or help shorten waiting lists. This uncertainty was reflected in their opinion of the use of a live video link, with around one third of respondents being unsure of its use compared with a store and forward system.

\section{Usefulness of a teledentistry system for patients}

The advantages of the system for patients were perceived as good, with only $10 \%$ or less of respondents disagreeing or strongly disagreeing with statements highlighting the merits of a teledentistry system (Table 2). More than half the GDPs agreed strongly that a teledentistry system would benefit patients in distant or rural locations.

\section{Usefulness of a teledentistry system for GDPs}

Around half of the respondents thought that enough diagnostic information would be provided, but 20\% disagreed or disagreed strongly with this statement (Table 3). Generally, factors identified while developing the questionnaire, such as expense, increased time in the surgery and current fee structure, were confirmed as potential concerns by most GDPs.

\section{Security, confidentiality and consent}

Concerns about equipment security tended to be higher than those surrounding patient confidentiality and consent. It is not known why concerns were expressed about equipment security as more practices are becoming computerised and equipment including digital cameras could be covered under the practice's insurance (Table 4).

\section{DISCUSSION}

The concept of a teledentistry system for new patient orthodontic referrals was well received by GDPs in our survey. This is in agreement with general support from the Consultant Orthodontic Group of the British Orthodontic Society ${ }^{5}$ and dentists' opinions of an 
Table 3 GDPs' views on the usefulness of a teledentistry system

\begin{tabular}{|c|c|c|c|c|c|}
\hline & \multicolumn{5}{|c|}{ Frequency (Valid \%) } \\
\hline & $\begin{array}{l}\text { Agree } \\
\text { strongly }\end{array}$ & Agree & $\begin{array}{l}\text { Neither } \\
\text { agree } \\
\text { nor } \\
\text { disagree }\end{array}$ & Disagree & $\begin{array}{l}\text { Disagree } \\
\text { strongly }\end{array}$ \\
\hline \multicolumn{6}{|l|}{$\begin{array}{l}\text { A teledentistry } \\
\text { system would: }\end{array}$} \\
\hline $\begin{array}{l}\text { Provide adequate } \\
\text { diagnostic } \\
\text { information }\end{array}$ & $14(11 \%)$ & $50(40 \%)$ & $38(30 \%)$ & $22(18 \%)$ & $2(2 \%)$ \\
\hline $\begin{array}{l}\text { Be better supported } \\
\text { through changing } \\
\text { the current } \\
\text { fee structure }\end{array}$ & $36(29 \%)$ & $44(35 \%)$ & $42(34 \%)$ & $1(1 \%)$ & $2(2 \%)$ \\
\hline $\begin{array}{l}\text { Be too expensive } \\
\text { to set up }\end{array}$ & $41(33 \%)$ & $37(29 \%)$ & $37(29 \%)$ & $11(9 \%)$ & 0 \\
\hline $\begin{array}{l}\text { Save time } \\
\text { compared with } \\
\text { a referral letter }\end{array}$ & $10(8 \%)$ & 27 (21\%) & $37(29 \%)$ & $41(33 \%)$ & $11(9 \%)$ \\
\hline $\begin{array}{l}\text { Need an extra } \\
\text { appointment for } \\
\text { taking photographs }\end{array}$ & $26(21 \%)$ & $45(36 \%)$ & $31(25 \%)$ & $21(17 \%)$ & $2(2 \%)$ \\
\hline $\begin{array}{l}\text { Increase surgery } \\
\text { time spent with } \\
\text { the patient }\end{array}$ & $36(29 \%)$ & $54(43 \%)$ & $30(24 \%)$ & $6(5 \%)$ & 0 \\
\hline
\end{tabular}

\begin{tabular}{|c|c|c|c|c|c|}
\hline & \multicolumn{5}{|c|}{ Frequency (Valid \%) } \\
\hline & $\begin{array}{l}\text { Very } \\
\text { concerned }\end{array}$ & $\begin{array}{l}\text { A little } \\
\text { concerned }\end{array}$ & $\begin{array}{l}\text { No feelings } \\
\text { either way }\end{array}$ & $\begin{array}{l}\text { Not } \\
\text { particularly } \\
\text { concerned }\end{array}$ & $\begin{array}{l}\text { Not } \\
\text { concerned } \\
\text { at all }\end{array}$ \\
\hline Equipment security & $28(22 \%)$ & $51(41 \%)$ & $25(20 \%)$ & $15(12 \%)$ & $7(6 \%)$ \\
\hline $\begin{array}{l}\text { Patient } \\
\text { confidentiality } \\
\text { when images } \\
\text { are sent to the } \\
\text { hospital }\end{array}$ & $16(13 \%)$ & $39(31 \%)$ & $33(26 \%)$ & $25(20 \%)$ & $13(10 \%)$ \\
\hline $\begin{array}{l}\text { Potential for } \\
\text { tampering with } \\
\text { computer images }\end{array}$ & $8(6 \%)$ & $35(28 \%)$ & $38(30 \%)$ & $30(24 \%)$ & $15(12 \%)$ \\
\hline $\begin{array}{l}\text { Patient consent } \\
\text { for referral via } \\
\text { email }\end{array}$ & $8(6 \%)$ & 37 (29\%) & $33(26 \%)$ & $34(27 \%)$ & $14(11 \%)$ \\
\hline
\end{tabular}

online orthodontic advice service ${ }^{6}$ with the latter reporting that GDPs felt there were significant educational benefits from the online service. In addition, evidence has also cited many advantages of telemedicine which adds weight to a general optimism about its development. For example, it has been suggested that health service efficiency will be increased, travel times and costs will decrease and that there will be a positive impact on medical staffing shortages because of decreased time to diagnose a problem. ${ }^{7}$

From the GDPs' point of view, there was a trend for more positive feedback with respect to the efficiency benefits and advantages of the system for patients compared with advantages to GDPs and security of the system.
The support for the teledentistry concept was encouraging but must also be viewed in the light of the non-responders to this survey (34.5\%). It is possible that there was some response bias as the non-responders might not be supportive of the system. This was borne out by some letters received either from GDPs without computers or those who would not wish to use a teledentistry system. It might take more time before some GDPs would want to use this referral method, particularly in view of the implications for setting it up in practice. In addition, if the GDPs had used the teledentistry system described their comments may have been different to those received in this study. It would be interesting to re-evaluate GDP opinion when teledentistry is more widely used.

This study has highlighted where GDPs would need support to create and use an electronic referral system. In particular, set up costs (including IT support), increased surgery time and a fee to reflect this. Such factors have previously been identified as barriers to expanding telemedicine systems. ${ }^{2}$

In our recently completed trial (see part 1) GDPs took 15-20 minutes to collect records, download and send the referral per patient. It was therefore important to recognise these factors and to try to address them, in view of the perceived patient benefits. In addition, the concerns just highlighted may also go some way to explain why only just over half the GDPs agreed that a teledentistry system would be better than a referral letter.

Any referral system that increases communication between primary and secondary care and enhances guidance and advice to GDPs must be beneficial. However, an important question is whether the diagnostic information obtained is adequate for the health professional to make a clinically sound and reliable judgement. ${ }^{8}$ Concern over diagnostic validity has been addressed in the part 1 randomised controlled trial which assessed written, photographic and radiographic information as an aid to screening orthodontic referrals.

\section{CONCLUSIONS}

GDPs generally supported the use of a teledentistry system for new patient orthodontic referrals. Although perceived patient advantages were agreed, GDPs tended to be less sure about the impact on them in terms of set up expenses, time in the surgery and appropriate remuneration.

The authors gratefully acknowledge the support of The British Dental

Association Shirley Glasstone-Hughes Award, The British Orthodontic Society Houston Research Scholarship, GlaxoSmithKline, The Booth Charities, BNFL, The Roger Clutterbuck Charitable Trust, The Dalmia Charitable Fund.Thanks to the GDP practices who provided interview information to develop the questionnaire and those who responded to the questionnaire.

1. Wallace S, Wyatt J, Taylor P. Telemedicine in the NHS for the millennium and beyond. Postgrad Med J 1998; 74: 721-728

2. Grigsby J, Sanders J H. Telemedicine: Where it is and where it's going. Ann Intern Med 1998; 129: 123-127.

3. Rollert M K, Strauss R A, Omar Abubaker A et al. Telemedicine consultations in oral and maxillofacial surgery. J Oral Maxillofac Surg 1999: 57: 136-138.

4. Davies J. The use of video conferencing technology in orthodontic treatment planning. MSc thesis. University of Bristol, 1999.

5. Stephens C D, Cook J. Attitudes of UK consultants to teledentistry as a means of providing orthodontic advice to dental practitioners and their patients. J Orthod 2002; 29: 137-142.

6. Cook J, Edwards J, Mullings $C$, et al. Dentists' opinions of an online orthodontic advice service. J Telemed Telecare 2001; 7: 334-337.

7. Al Hassab M H A, Lu D M, Pan Y H. A review of telemedicine. J Telemed Telecare 1999; 5: 103-106.

8. Jerrold L. Litigation, legislation and ethics. The problems, electronic data transmission and the law. Am J Orthod Dentofacial Orthop 1998; 113: 478-479. 